\title{
Studi Kualitatif Penyebab Kematian Perinatal
}

\section{Qualitative Study Of Perinatal Death Causes}

\author{
Deni Maryani \\ Prodi DIII Kebidanan, Fakultas MIPA Universitas Bengkulu \\ Email : dmaryani@unib.ac.id
}

\begin{abstract}
ABSTRAK
Kemampuan penyelenggaraan pelayanan kesehatan suatu bangsa diukur dengan menentukan tinggi rendahnya angka kematian ibu dan perinatal. Angka kematian perinatal merupakan penyumbang terbesar tingginya angka kematian bayi. Badan kesehatan dunia memperkirakan lebih dari 9 juta bayi setiap tahun meninggal sebelum lahir dan pada minggu pertama kehidupanya dengan penyebab kematian $2 / 3$ nya berasal dari penyebab yang dapat dicegah. Tujuan penelitian ini adalah untuk mengetahui penyebab kematian perinatal. Jenis penelitian yang digunakan adalah penelitian kualitatif, untuk mendapatkan informasi yang mendalam tentang bagaimana menganalisis penyebab kematian perinatal di Kabupaten Bandung. Data dikumpulkan melalui wawancara mendalam, dan melakukan reduksi data, penyajian data dengan trianggulasi sumber dan trianggulasi metode. Data dianalisis dengan menggunakan analisis isi yaitu membandingkan hasil penelitian dengan teori-teori yang ada dikepustakaan. Informan dalam penelitian ini sebanyak 11 informan. Hasil penelitian menunjukkan penyebab kematian perinatal sangat berkaitan dengan tempat pelayanan awal bukan di fasilitas kesehatan, kepercayaan pada pengobatan tradisional, keterlambatan rujukan, kualitas rujukan, dan fasilitas RS tempat rujukan.
\end{abstract}

Kata kunci: Kematian, Perinatal, Kualitatif

\begin{abstract}
The ability to administer a nation's health services is measured by determining the high and low maternal and perinatal mortality rates. The perinatal mortality rate is the largest contributor to the high infant mortality rate. WHO estimated that more than 9 million babies die each year before birth and that during the first week of life the 2/3 causes of death originate from preventable causes. The purpose of this study was to study the causes of perinatal death. The type of research used was qualitative research, to obtain in-depth information about how to analyze the causes of perinatal death in Bandung Regency. Data was collected through in-depth interviews, and data reduction, data presentation with source triangulation and method triangulation. Data were analyzed using content analysis, namely comparing the results of research with the theories in the library. The informants in this study were 12 informants. The results showed that the causes of perinatal death were strongly related to the initial place of service not to health facilities, trust in traditional medicine, late referrals, quality of referrals, and facilities for referral hospitals.
\end{abstract}

Keywords: Death, Perinatal, Qualitative

\section{PENDAHULUAN}

Informasi kematian anak, yang terdiri dari angka kematian neonatal $(\mathrm{AKN})$, angka kematian bayi, (AKB), dan angka kematian balita (AKABA) merupakan indikator penting untuk menilai tingkat kesejahteraan termasuk derajat kesehatan suatu negara serta kualitas hidup (SDKI, 2017).

Badan kesehatan dunia (WHO) pada Tahun 2016 memperkirakan lebih dari 9 juta bayi setiap tahun meninggal sebelum lahir dan pada minggu pertama kehidupanya (periode perinatal) dan 
hampir semua kematian perinatal (Perinatal Mortality Rate) terjadi di negara berkembang, dengan sebab kematian yaitu prematur, BBLR, infeksi, asfiksia, kelainan kongenital dan trauma persalinan (Kemenkes RI, 2015).

Kemampuan penyelenggaraan pelayanan kesehatan suatu bangsa diukur dengan menentukan tinggi rendahnya angka kematian ibu dan perinatal, namun pada saat ini angka kematian perinatal masih tinggi. Angka tersebut seharusnya dapat dicegah dengan cara memberikan pelayanan kesehatan terutama pada pertolongan pertama persalinan. Kematian perinatal adalah bayi lahir mati yang terjadi setelah kehamilan berusia 28 minggu ( 7 bulan) dan bayi meninggal sebelum berumur tepat satu minggu. Angka kematian perinatal merupakan penyumbang terbesar tingginya angka kematian bayi (Michalow, 2015).

Provinsi Jawa Barat menjadi salah satu provinsi yang berkontribusi besar terhadap kematian bayi di Indonesia. Hasil survey pendahuluan didapatkan jumlah kematian perinatal di Jawa Barat tahun 2014 adalah 2.563 dengan rincian jumlah lahir mati 1.055 dan kematian neonatal dini adalah 1.508, dengan penyebab kematian adalah
BBLR (31\%), asfiksia (27,3\%), dan lainlain (20,1\%) (Dinkes Jawa Barat, 2015).

Jumlah kematian perinatal di Kabupaten Bandung tahun 2015 adalah 221, dengan jumlah kelahiran di Kabupaten Bandung tahun 2015 adalah 64.849, penyebab kasus tertinggi adalah BBLR (Dinkes Kabupaten Bandung, 2015).

Penyebab kematian perinatal 2/3 nya berasal dari penyebab yang dapat dicegah. data hasil audit tentang faktor penyebab kematian perinatal diantaranya dari faktor pasien, perilaku kesehatan, faktor rujukan dan faktor sarana penunjang ( Merali, 2014).

Survey awal didapatkan kasus tentang kematian perinatal terjadi di RS rujukan, mengapa hal ini bisa terjadi, apakah disebabkan oleh rujukan yang terlambat, fasilitas rujukan yang kurang atau sebab lainnya, untuk itu diperlukan informasi yang mendalam tentang penyebab kematian perinatal.

Tujuan penelitian ini adalah untuk mengetahui penyebab kematian perinatal.

\section{METODE PENELITIAN}

Penelitian ini menggunakan metode kualitatif untuk mendapatkan informasi yang mendalam tentang 
penyebab kematian perinatal. Informasi tentang penyebab kematian perinatal berasal dari Puskesmas, bidan desa dan ibu yang mengalami bayinya meninggal pada usia perinatal pada Kecamatan Majalaya dan Kecamatan Pangalengan. Data dikumpulkan dengan menggunakan metode wawancara mendalam. Pengambilan sampel secara purposive sampling Sebelumnya informan diminta persetujuan untuk diwawancara dengan menandatangani formulir informed consent. Untuk menjaga validitas data digunakan trianggulasi sumber.

\section{HASIL DAN PEMBAHASAN}

1. Tempat Pelayanan Awal

Masih adanya masyarakat yang mencari pertolongan pertama bukan pada tenaga kesehatan, ini menjadi perhatian khusus karena dari awal pertolongan akan menentukan kondisi pasien selanjutnya bila kondisi pasien sudah parah penanganan akan kurang optimal lagi, paraji di Kabupaten Bandung yang jumlahnya melebihi jumlah bidan menjadi salah satu penyebab kematian perinatal yang ditolong oleh paraji. Jumlah paraji di Kabupaten Bandung tahun 2015 jumlahnya lebih banyak dari pada bidan, seperti yang diungkapkan oleh responden.

"Sebenarnya pertolongan oleh paraji sudah tidak dibolehkan, tetapi jumlah paraji di Kabupaten Bandung ini 792 orang dan jumlah bidan 559, susah untuk menghilangkan peran paraji...(RI Indpt)"

Banyak upaya yang telah dilakukan untuk menghilangkan kebiasaan melahirkan dengan paraji, karena bila pertolongan yang dilakukan oleh paraji, banyak menyebabkan komplikasi yang berakhir pada kematian.

"Untuk paraji kami dari puskesmas dan bidkor rutin melakukan penyuluhan ke desa dan melibatkan peran kader kesehatan... tapi ya itu masih saja ada yang melahirkan sama paraji dan terjadi komplikasi... dengan alasan keberosotan (R2 Indpt)"

"Disini kalo ANC nya bagus ada yang sebulan dua kali tapi ya itu kalo lahiran sama paraji.... gak tau karna dari temurun ibunya lahiran sama paraji ya.... anaknya harus lahiran sama paraji juga...(R3 Indpt)” 
2. Tempat kematian

\section{Keterlambatan penanganan}

kasus kegawatdaruratan perinatal akan berpengaruh pada gagalnya penyelamatan perinatal. Banyak kasus kematian perinatal berawal dari kondisi pada saat datang sudah sangat parah atau terlambat sekali, sehingga kematian perinatal di Rumah Sakit atau di fasilitas rujukan angkanya tinggi, dan masih ada terjadi rujukan yang berkeliling dulu untuk mencari RS disebabkan karena kurangnya fasilitas kesehatan sehingga pasien harus dirawat dengan peralatan seadanya sampai bayi meninggal serta alas an lain karena RS yang memiliki fasilitas yang mendukung sudah penuh pasienya, Beberapa hal yang menyebabkan kegagalan misalnya pada saat sampai di Rumah Sakit, pasien sudah dalam keadaan yang parah sehingga upaya yang dilakukan tidak optimal lagi.

"Kadang pasiennya datang sudah dari dukun, kita terima sudah parah.(R4 Indpt)"

Masih ada kasus kematian
yang terjadi bukan ditempat
pelayanan kesehatan atau non fasilitas
kesehatan seperti dijalan dan dirumah

seperti kematian perinatal terjadi dijalan menuju tempat rujukan.

“ada juga si bu... yang meningggal dijalan mau di bawak ke RS tapi sudah meninggal, ya... karena sudah parah juga kalo bayi sudah sesak biru (R5 Indpt)”,

"Bayinya sudah meninggal karena ditolong paraji dirumah... baru panggil bidannya(R6 Indpt)"

3. Keterlambatan rujukan

Penyebab keterlambatan dalam proses rujukan perinatal diantaranya karena terlambat mengenali tanda bahaya, terlambat mengambil keputusan, ketersediaan transportasi, ketersediaan biaya, ketidakmampuan ibu dalam mengambil keputusan untuk keselamatan dirinya, terlambat sampai ke fasilitas kesehatan, sampai di fasilitas rujukan terkendala dengan terbatasnya fasilitas penunjang pasien, sering dihadapkan dengan kondisi rumah sakit yang penuh sehingga harus berpindah-pindah rumah sakit, dan beberapa kasus keluarga menolak untuk dirujuk ke fasilitas kesehatan yang lebih lengkap dengan terpaksa hanya diberikan pelayanan kesehatan yang seadanaya sampai akhirnya pasien meninggal. 
"Ya itu pengambilan keputusan teh...disini banyak yang nikah muda jadi ya keputusan banyak di orang tua..(R3 Indpt)"

“....,Iya paling jalan... apalagi malam kalo malam gelap kalo siang muter jauh... jalan jelek atuh, belum kena alat-alat, setengah jam lah.....(R8 Indpt $) ”$

4. Kualitas rujukan

Ketersediaan SDM yang profesional baik secara kualitas maupun kuantitas diperlukan untuk meningkatkan layanan yang baik terutama pada saat terjadi keadaan gawat darurat.

“Kalo pasiennya tidak gawat kadang pergi sendiri ke RS atau kalo siang ke puskesmas dulu minta rujukan (R10 Indpt)"

5. Ketersediaan alat di RS

Ketersediaan obat dan alat berhubungan juga dengan keterlambatan penanganan ditempat rujukan dan menjadi kendala karena kurangnya tenaga perawat dan tenaga spesialis di Rumah Sakit hanya sedikit sehingga layanan rujukan kurang maksimal, dokter spesialis tidak bisa stand bay 24 jam di Rumah Sakit, hal ini sangat berpengaruh pada pelayanan terutama pelayanan pada malam hari.

"Disini pasiennya banyak bu, tapi alatnya gak lengkap makanya banyak yang meninggal. Gak punya ruang intensif (R11 Idpt)"

Tempat pelayanan awal akan memengaruhi terjadinya komplikasi perinatal, harapan tempat pelayanan awal akan ditolong oleh tenaga kesehatan dan akan mampu mendeteksi secara dini tanda-tanda yang mengarah pada komplikasi, ketika ditemukan tanda-tanda komplikasi akan mampu memberikan penanganan awal yang efektif sehingga komplikasi tidak berlanjut parah atau bisa ditangani dan tidak terjadi kematian perinatal.

Penolong pertama bukan pada tenaga kesehatan merupakan faktor risiko bagi terjadinya kematian maternal yang secara langsung akan memengaruhi bayi yang di kandung atau yang dilahirkan. Sejalan dengan penelitian yang dilakukan di Kabupaten Bone dengan metode wawancara mendalam menyatakan bahwa pengetahuan dukun tentang tanda bahaya pada persalinan hanya perdarahan, jika terjadi kejangkejang atau eklampsi atau solusio plasenta mereka hanya menganggap itu hanya merupakan sapaan dari mahluk 
halus ketika keluar rumah dimalam hari. Pengetahuan yang sangat terbatas ini dapat menjadi penyebab kematian ibu dan bayi. ( Parenden, 2015) Penolong persalinan terlatih mampu menurunkan kematian bayi baru lahir sekitar $43 \%$ dan mencegah dua pertiga dari kematian maternal. Penolong persalinan terlatih di tingkat pelayanan kesehatan primer perlu bekerja dengan penyedia layanan lainnya di masyarakat,seperti dukun beranak dan pekerja sosial (Merali, 2014).

Persalinan yang aman dan bersih, pelayanan serta pendekatan petugas kesehatan yang lebih baik, dapat memengaruhi ibu dalam memilih tempat persalinan, selain karena dipengaruhi oleh keterjangkauan masyarakat terhadap fasilitas kesehatan. Ditingkat komunitas, pelayanan ANC, persalinan, dan nifas ditentukan oleh tanggapan fasilitas kesehatan terhadap kebutuhan ibu yang berhubungan dengan kemudahan dalam menjangkau akses tenaga kesehatan. (Parenden, 2015) Jarak pelayanan kesehatan yang tidak terjangkau oleh masyarakat dapat mengakibatkan masyarakat memilih untuk mencari pertolongan persalinan yang lebih dekat. Penelitian yang sama dilakukan oleh Kebakyenga di Uganda dalam (Parenden, 2015) menyatakan alas an utama pemilihan penolong persalinan $228(49,8 \%)$ dari mereka menjawab karena jarak dari rumah ke fasilitas kesehatan terlalu jauh, 224 (48,8\%) percaya pada dukun, dan $164(35,8 \%)$ mengatakan karena tidak ada sarana transportasi, $99(21,6 \%)$ adalah tidak perlu untuk persalinan.

Ada beberapa hal yang memengaruhi proses rujukan misalnya dari transportasi, geografis, wilayah tempat tinggal, waktu tempuh, jarak tempat tinggal, biaya, dan keputusan keluarga. Hal ini sesuai dengan hasil penelitian di Tanzania menyebutkan bahwa $72,5 \%$ kematian bayi diakibatkan oleh lebih dari satu faktor keterlambatan. $35,8 \%$ kematian bayi disebabkan oleh karena keterlambatan yang diakibatkan oleh karena terlambatnya bayi dibawa ke fasilitas pelayanan kesehatan. Hal ini disebabkan oleh transportasi yang buruk dan jauh serta tidak percayanya keluarga dengan fasilitas atau tenaga kesehatan untuk melakukan pertolongan terhadap kegawatdaruratan yang terjadi ( Munjanja, 2012).

Kondisi geografis ini juga merupakan salah satu penyebab terlambat mencapai fasilitas kesehatan (second delay). Di Pakistan, dari 104 
kematian, $74 \%$ diantaranya terjadi karena "second delay" yang mana penyebabnya adalah jarak yang jauh. Hal ini berarti mereka juga mendapat keterlambatan dalam penanganan. Di Uganda, keadaan geografis dan infrastruktur transportasi yang belum memadai sangat memengaruhi akses ke fasilitas kesehatan. Banyak wanita di Uganda yang harus berjalan berkilokilometer untuk mencapai fasilitas kesehatan yang tentunya berpengaruh terhadap kematian, baik ibu maupun bayi (Tuyisenge, 2011).

Ketersediaan obat dan alat bisa menjadi faktor pasien menjadi terlambat mendapat petolongan, selain obat dan alat yang dibawa pada saat merujuk juga kesediaan alat dan obat di tempat rujukan. Kematian ibu yang terjadi pada saat terlambat mendapatkan pelayanan ditempat rujukan disebabkan karena kurangnya fasilitas obat-obatan, kurangnya peralatan, kurangnya staff yang terlatih dan kompeten menjadi penyebab kematian ibu di Gambia (Aghamohammadi, 2011).

Jumlah tenaga kesehatan yang kurang dan kompetensi yang rendah ikut memberikan dampak terhadap pelaksanaan sistem rujukan. Penelitian di Kabupaten Lingga yang menemukan bahwa jumlah tenaga kesehatan terutama dokter umum dan spesialis yang kurang dan kompetensi pegawai di sarana pelayanan kesehatan penerima rujukan yang masih rendah menyebabkan terganggunya pelaksanaan sistem rujukan. Permasalahan dalam sistim rujukan diantaranya: sistem komunikasi, adalah akses komunikasi yang terbatas menyebabkan masyarakat mengalami kesulitan dalam menghubungi sarana rujukan, permasalahan ini sebagian besar terjadi di daerah pedesaan (Mbaruku, 2009).

\section{SIMPULAN DAN SARAN}

Kematian perinatal disebabkan karena tempat pelayanan awal yang dibeikan bukan pada pelayanan kesehatan, masyarakat masih percaya dengan pengobatan tradisional paraji, sehingga kematian banyak terjadi di fasilitas kesehatan. Keterlambatan dalam mengambil keputusan menjadi penyebab lain kematian perinatal, keluarga terlambat dalam mengambil keputusan, kualitas rujukan juga belum maksimal, dan RS tempat rujukan belum memiliki alat atau fasilitas pendukung perawatan perinatal. Perlu upaya untuk meningkatkan pengetahuan masyarakat tentang penyebab terjadinya kematian 
perinatal, berobat pada fasilitas kesehatan, mengurangi atau menghilangkan keyakinan berobat pada paraji, mengetahui tanda bahaya pada ibu dan bayi sehingga tepat dalam pengambilan keputusan dalam keluarga. Lebih meningkatkan pengetahuan tenaga kesehatan dalam proses rujukan serta meningkatkan sarana dan prasarana di RS rujukan.

\section{DAFTAR PUSTAKA}

Aghamohammadi A, Noortarijor M. 2011. Maternal Age as a Risk Factor for Pregnancy Out Comes: Maternal, Foetal and Neonatal Complication. African Journal of Pharmacy and Pharmacology:;5(2):264-9.

Dinas Kesehatan Provinsi Jawa Barat. 2014. Profil kesehatan Jawa Barat. Jawa Barat.

Dinas Kesehatan Kabupaten Bandung. 2015. Laporan tahunan kesehatan Kabupaten Bandung. Soreang.

Kemenkes RI. 2015. Pedoman audit maternal-perinatal di tingkat Kabupaten/ Kota.

Merali HS, et al. 2014. Audit-identified avoidable factors in maternal and perinatal deaths in low resource settings: a systematic review. BMC.14(280):1-12.

Michalow J, et al. 2015. Triple return on investment: the cost and impact of 13 interventions that could prevent stillbirths and save the lives of mothers and babies in South Africa. BMC.15(39):1-13.

Munjanja SP, Magure T, Kandawasvika G. 2012. Geographical access transport and referral systems. $\mathrm{J}$ Hussein.139-54.

Mbaruku G, et all. 2009. Perinatal audit using the 3-delays model in western Tanzania. International Journal of Gynecology and Obstetrics.106:85-8.

Newborns: Reducing Mortality. Word Health Organization; 2016.

Parenden RD, Kandou GD, Pangemanan JM. 2015. Analisis keputusan ibu memilih penolong persalinan diwilayah Puskesmas Kabila Bone. JIKMU.5(2):362-372.

Survey demografi kesehatan Indonesia 2017. In: BKKBN, BPS, Kemenkes, editors. Jakarta.2018.

Tuyisenge G. 2015. Mothers' Perceptions and Experiences of Accessingm Maternal Health Care : Exploring the Role of Community Health Workers and Continuing Professional Development in Rwanda. London, Ontario, Canada: University of Western Ontario. 